\title{
7. \\ ROMAN ZIMSKO LJETOVANJE \\ VLADANA DESNICE U SVJETLU \\ KULTURALNIH STUDIJA
}

\section{Vladimir Rismondo}

UDK: 316.7:821.163.42-3Desnica, V.

Prethodno priopćenje

Sažetak: Autor se fokusira na odnos urbane i ruralne Dalmacije, viđen kroz prizmu romana Zimsko ljetovanje Vladana Desnice. Također se u kontekstu romana obrađuju dvije paradigme prisutne u Splitu i Dalmaciji tijekom prve polovine 20. stoljeća: prva je određena mišlju Benedetta Crocea, a druga, utjecajnija, intonirana postojanjem „narodnjačkog" modela, vidljivog poglavito u ranom opusu Ivana Meštrovića, a potom i u radu nekih njegovih splitskih sljedbenika. Instrumentarij kojim se navedene paradigme ispituju temelji se na preplitanju „teorije drugoga“" (teorije konstrukcije identiteta“) i imagoloških studija. Imagološka terminologija - relevantna za odnos ruralnog i urbanog u Dalmaciji - također se oblikuje kroz politički rivalitet „narodnjaštva“ $i$,talijanaštva“, gdje obje orijentacije grade vlastite konstrukcije identiteta. U tome je daleko uspješnija bila „narodnjačka“ struja koja se naslanjala na romantično viđenje južnoslavenske ideologije, uprizorene prije svega u Kosovskom ciklusu Ivana Meštrovića, a potom i u segmentima opusa nekih njegovih sljedbenika i suradnika.

Ključne riječi: Vladan Desnica, Zimsko ljetovanje, Benedetto Croce, Ivan Meštrović, folklor etniciteta, identitet, „teorija drugoga“

\section{UvoD}

T zlaganje obrađuje odnos dvaju društvenih identiteta prisutnih u Splitu i Dalmaciji od vremena kada ih je, uvjetno rečeno, prvi put - kroz antagonizam grada i njegovog ru$\int$ ralnog zaleđa u 13. stoljeću naznačila Historia Salonitana Tome Arhiđakona ${ }^{1}$ - pa sve do kraja prve polovine 20. stoljeća. Fokus je na krajnjem izvodu tog odnosa u vidu razlikovanja dviju imagološki relevantnih paradigmi koje očitavamo tijekom prve polovine 20. stoljeća. Ona danas manje poznata podcrtana je građanskom misli Benedetta Crocea, a druga - daleko poznatija - postojanjem „narodnjačkog“ modela, oblikovanog u Kosovskom

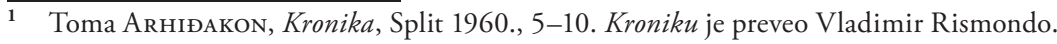


ciklusu Ivana Meštrovića, odnosno njegovim utjecajima na krug mlađih splitskih kipara. Analitički instrumentarij kojim ćemo se služiti u promišljanju navedenih paradigmi temelji se na prepletanju dvaju kulturološki relevantnih modela.

Prvi model počiva na „teoriji drugoga“, koju smatramo granom „teorije konstrukcije identiteta“. ${ }^{2}$ Poimanje "drugog" temeljeno je na prethodnoj identifikaciji normativnog (društvenog, etičkog i estetičkog) ,jastva“, odnosno „prvog“ i dominantnog društvenog identiteta. Drugi analitički model proizlazi iz imagoloških studija. Radi se o disciplini u sastavu teorije književnosti koja izučava konstrukcije i reprezentacije kolektivnih identiteta. ${ }^{3}$ Imagološka analiza počiva na predodžbenoj jedinici „slike“, odnosno motivu koji posjeduje vrijednost reprezentacije. Stvarajući takvu slikovnu predodžbu o „drugom“, „jastvo“ govori o sebi, odnosno vlastitom konceptualnom strukturiranju. Naposljetku, kontekstualni okvir za razmatranje navedenih paradigmi nalazimo u romanu Zimsko ljetovanje, koji Vladan Desnica objavljuje 1950. Prvenstvo imagološkog istraživanja ovog romana pripada Mirni Sindičić Sabljo, koja 2011. u Desničinom tekstu istražuje suprotstavljene predodžbe sela i grada. ${ }^{4}$

\section{ETIČKI POLOVI ROMANA}

Miljenko Jergović roman Zimsko ljetovanje Vladana Desnice naziva prvim i jedinim građanskim romanom o Drugom svjetskom ratu u hrvatskoj i bliskim joj književnostima. ${ }^{5}$ Desničin tekst uz ostalo kazuje o bombardiranju Zadra od strane savezničkih snaga, a koje se događalo u periodu od studenog 1943. do listopada 1944. Tijekom bombardiranja nestalo je - ponovno Jergović - mjesto građanskog, romansko-slavenskog sinkretizma, ${ }^{6}$ a Desnica koristi opisani povijesni okvir da bi razmotrio kušnje nekoliko građanskih zadarskih obitelji; bježeći od razaranja, one nalaze pribježište na imaginarnom toponimu Smiljevci u zadarskom zaleđu. Stanovnici Smiljevaca u romanu su okarakterizirani kao „drugi“, odnosno, iz perspektive zadarskih građana viđeni su kao nosioci ruralnog habitusa. Roman se fabularno svodi na opis prisilnog suživota, razotkrivanja različitosti i latentnog sukoba dva mentaliteta. Njihov sraz završava tragičnim događajem simboličke vrijednosti: seoski prasac Migud proždire bebu Špižmicu - dijete jedne od izbjeglih obitelji - čime kao da se najavljuje ishod rata po zadarske građane; neovisno o nacionalnoj i ideološkoj pripadnosti, oni u konačnici bivaju pojedeni od „drugih“?

2 Vidi: Stuart Hall - Paul du GAY (ur.), Questions of Cultural Identity, London 2011.

3 Vidi: Manfred Beller - Joep Leerssen, Imagology. The Cultural Construction and Literary Representation of National Characters, Amsterdam - New York 2007., 3-16, 63-75.

4 Mirna Sindičić SABljo, „Predodžbe o ruralnoj sredini u Zimskom ljetovanju Vladana Desnice“, Fluminensia, 23/2011., br. 1, 131-142.

5 Miljenko Jergović, „Vladan Desnica: Hitac veselnik“, Subotnja matineja (http://www.jergovic.com/subotnja-matineja/vladan-desnica-hitac-veselnik/).

6 Isto.

7 Vladan Desnica, Zimsko ljetovanje; Pripovijesti (= Pet stoljeća hrvatske književnosti, knj. 117, prir. Vlatko Pavletić), Zagreb 1968., 169-170. 
Imajući u vidu godinu nastanka, tekst romana Zimsko ljetovanje može se shvatiti poput rane slutnje „teorije konstitutivnog drugog“" koju će gotovo tri desetljeća kasnije, 1978., popularizirati Edward W. Said u studiji Orijentalizam. ${ }^{8}$ Kao što je poznato, radi se o dekonstrukciji načina na koji se stvarala europocentrična kulturalna reprezentacija orijentalnih društava. Saidovo pitanje - gdje počinje „drugi“ (Orijentalac“), a gdje završava normativno europocentrično ,jastvo“ - jednako je značajno za Desničin roman (u kojem je „Orijentalac“ imagološki zamijenjen „Smiljevčaninom“, a „Europejac“ se premeće u „Zadranina“), ali i za konstrukciju društveno - političkih identiteta u Dalmaciji tijekom druge polovine 19. te prve polovine 20. stoljeća. Opisana dvojnost ima i dvije imagološki značajne povijesne pretpostavke. Prva je studija Roberta Adama Ostaci Dioklecijanove palače u Splitu u Dalmaciji iz 1764. ${ }^{9}$ Tekst je praćen šezdeset i jednim bakrorezom s prikazima palače. Na nekima od njih, u skladu s pravilima reprezentacije arhitekture tijekom 18. stoljeća, vide se ljudski likovi odjeveni u orijentalnu nošnju; time se naznačuju imaginacijske fusnote kojima je europska misao ocrtavala Mediteran. Radi se o izvoru klasične kulture koji je u međuvremenu „orijentaliziran“, degradiran, te u trenutku stvaranja predodžbenog modela prebiva među razvalinama klasične civilizacije. Poimanje naslijeđa klasične kulture prešlo je, pak, već tada na sjeverozapad Europe, a Mediteran postaje poprištem „Grand Toura“, edukativnog putovanja sa sjevera u srce Mediterana, kojim novi Europejci kolonijalno potvrđuju nadmoć nad starima. ${ }^{10}$

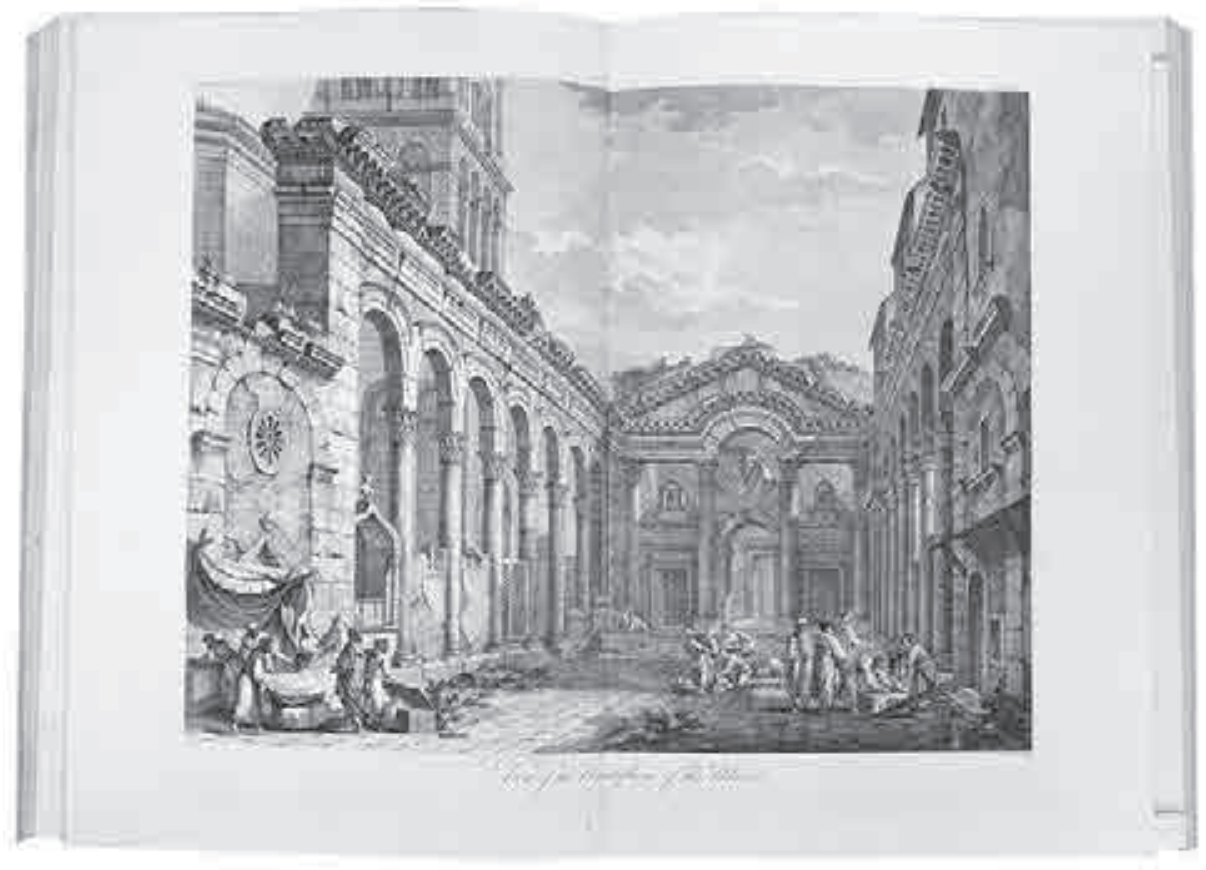

Sl. 1. Bartolomeo Nerici, Peristil (18. stoljeće)

\footnotetext{
Vidi: Edward SAID, Orientalism, London 1978.

9 Vidi: Duško Keč́nmet, Robert Adam: Dioklecijanova palača i klasicizam, Zagreb 2003.

10 Vidi: Lisa Colletta (ur.), The Legacy of Grand Tour, New Jersey 2015.
} 
Drugu pretpostavku predstavlja putopisni tekst Alberta Fortisa Putovanje po Dalmaciji iz $1774 .{ }^{11} \mathrm{U}$ tom su tekstu iznesena zapažanja vezana uz Morlake, stanovnike zaleđa dalmatinskih gradova, gdje pisac naglašava razliku mentaliteta između urbanih "primoraca“ i ruralnih „zagoraca“. Prve doživljava „pravim potomcima rimskih kolonija“, dok su drugi „oni koji uzastopno mijenjaju domovinu za vrijeme provala i ratova“. ${ }^{12}$ Za naš je rad značajno Fortisovo potcrtavanje činjenice prema kojoj je Morlak „posve različito moralan od nas“. ${ }^{13}$ Nećemo ulaziti u analizu Fortisovih pogleda na Morlake, već ćemo uočiti da naglašava ono „nas“ u vidu konstrukcije normativnog ,jastva“, čime Morlake - bez obzira na čuđenje i simpatije koje prema njima gaji - smatra „drugima“. U tom ćemo smislu prihvatiti sud Alena Tafre prema kojem Fortisova „Dalmacija predstavlja prostor triplex confinium-a na kojemu se latinski Zapad neposredno dodiruje s Istokom, gdje je potonji među sobom podijeljen na grčko-pravoslavni i onaj islamsko-orijentalni “ ${ }^{14}$ Radi se o prostoru dva suprotstavljena identiteta gdje onaj latinski sebe doživljava kao normativno „jastvo“, a orijentalni i ruralni entitet vidi kao doslovno „drugog“. Opisana podvojenost nije samo plod putopisne imaginacije 18. stoljeća - Nikša Stančić citira tekst iz La voce Dalmatica, koji još oko 1860. godine izrijekom spominje fortisovsku razdvojenost Dalmacije putem jezika i kulture. ${ }^{15}$

Desničin roman Zimsko ljetovanje sukobljava oba pola ove razdvojenosti, a imagološki najupečatljivija slika kojom pojašnjava o čemu se radi tiče se pogleda na bombardiranje Zadra iz perspektive Smiljevaca. Naime, izbjeglice promatraju događaje u gradu s vremenskim i prostornim odmakom, kao da Smiljevci postoje u paralelnoj stvarnosti koja samo registrira događaje iz urbanog realiteta. K tome, baš tijekom bombardiranja Smiljevčani likuju nad sudbinom grada i njegovih stanovnika te ostaju nesolidarizirani s patnjama gradskog stanovništva, koje doživljavaju iz perspektive vlastitog normativnog ,jastva“. ${ }^{16}$ Desnica jasno razotkriva različite moralne pretpostavke Smiljevčana i zadarskih izbjeglica. Potonji se - slijedimo li podjelu Josepha M. Bryanta - rukovode tzv. „etikom krivnje“, koja naglašava princip osobne savjesti u izboru između dobra i zla. ${ }^{17}$ Pisac će taj etički kompleks sažeti u svjetonazoru Zadranina šjor Karla, koji vjeruje u pobjedu dobra osnaženog civilizacijskim postignućima. ${ }^{18}$ Odgovor Smiljevčana, pak, dat je iz perspektive suprotstavljenog ruralnog etosa, a kroz usta seljaka Milenka koji glorificira „ljudstvo“, „starešinstvo“, „crkvu“ i znanje o tome „ko ima slušati a ko zapovijedati “. ${ }^{19}$ Milenkovo etičko credo isključuje razloge djelovanja koji su „etici krivnje“ važniji od konačnog učinka. Ono proizlazi iz morlačke „etike stida“, koja predstavlja verziju poznatije „aretističke etike“ bazirane na tradiciji, nužnosti i

\footnotetext{
11 Vidi: Alberto Fortis, Put po Dalmaciji, Split 2004.

12 Isto, 37-39.

13 Isto, 39.

14 Alen TAfra, „Dodir Mediterana i Istočne Europe u svjetlu 'filozofske geografije”“, Metodički ogledi, 18/2011., br. 1, 67-82.

15 Nikša StANČıć, „Nacionalna integraciona ideologija dalmatinskih narodnjaka 1860/61. godine“, Radovi Zavoda za hrvatsku povijest, 11/1978., 183-279.

16 V. Desnica, Zimsko ljetovanje, 64-65.

17 Vidi: Joseph M. Bryant, Moral Codes and Social Structure in Ancient Greece. A Sociology of Greek Ethics From Homer to the Epicureans and Stoics, NewYork 1996.

18 V. Desnica, Zimsko ljetovanje, 128.

19 Isto, 157.
} 
časti. ${ }^{20}$ Milenko, dakle, pripada ruralnom etosu, koji čin vrednuje s pozicija onoga što zajednica očekuje od pojedinca, te time praćenog latentnog stida, odnosno načina njegovog potiskivanja. Desnica će u tom smislu oko problema vezanih uz „etiku stida“ oformiti niz imagološki zanimljivih motiva. Primjerice, Smiljevčanka Ika, žena bolesnog Nikice, brinut će se za muža ustrajnošću identičnom onoj kojom Homerova Penelopa čeka Odisejev povratak uz šturo obrazloženje: „A eto, čovjek mi je.“21 Također, kad opisuje mušku potrebu za nošenjem puške, Desnica nas suočava s aretističkim, konkretnije hajdučkim predodžbama junaštva temeljenima na fizičkoj snazi i moći koju donosi rukovanje oružjem. ${ }^{22} \mathrm{Na}$ posljetku opisujući prasca Miguda, pisac portretira aretistički ideal životinje: „Nije to bilo prase nego krmak, i to kakav krmak! Ogroman, silne pojave... izgledao je ne pojedinačni, živ krmak nego sam spomenik svinjskom rodu. "23 Opisana etička, a zapravo kulturna suprotstavljenost, prema Davoru Dukiću, ipak, predstavlja tek jedan (mada Desnici i jedini relevantan) od pet mogućih srazova Zadrana i Smiljevčana. Dukić, naime, govori o etničkom, konfesionalnom, jezičnom, političkom i socio-kulturnom srazu, koje Desnica opisuje $s$ više ili manje analitičnosti, a socio-kulturno antagoniziranje Dukić smatra i jedinim koje bi Desnica kao građanski elitist, kozmopolit i istraživač svjetonazora smatrao dostojnim razmatranja. ${ }^{24}$

\section{IMAGOLOŠKI IZVODI}

Vidimo kako se - konstruirajući sraz ruralnog s urbanim etosom - Desnica služi podjelom koja u Dalmaciji ne predstavlja novost. Naprotiv, imagološki gledano, predodžbene slike putem kojih naposljetku nastaju ideje o dvije Dalmacije, gradile su se (čak i ako zaboravimo fortisovska zapažanja o društvenoj podijeljenosti ovog područja) kroz proces političkog sazrijevanja Dalmacije u drugoj polovini 19. stoljeća. Jedan od važnijih elemenata toga procesa predstavlja politički sukob narodnjaštva s autonomaštvom. Sukob nadilazi polemiku Natka Nodila s Nikolom Tommaseom iz 1862. godine, ali upravo unutar te polemike nalazimo terminološke odrednice koje će markirati simboliku predodžbenih slika s kojima, pak, još sredinom 20. stoljeća, pišući tekst romana Zimsko ljetovanje barata Vladan Desnica. Konačno, radi se o sukobu koji pozicije gradi oko općih jezičnih i političkih pitanja (ilirski ili talijanski jezik, dalmatinska autonomija ili sjedinjenje Dalmacije s hrvatskim, pa i mnogo širim zaleđem, itd.), ali se u suštini temelji na ideološkom tkivu tipičnom za 19. stoljeće. Naime, Nodilo će u djelu Stara vjera Srba i Hrvata veličati narod kao takav. ${ }^{25}$ Što je prema tome „narod“ za Nodila?

\footnotetext{
J. M. Bryant, Moral Codes and Social Structure, 27-39.

V. Desnica, Zimsko ljetovanje, 81.

Isto, 154 .

Isto, 75 .

4 Davor Dukić, „Nekoliko imagoloških opaski o Zimskom ljetovanju i Desničinim susretima“, Desničini susreti 2005. - 2008. Zbornik radova (ur. Drago Roksandić i Ivana Cvijović Javorina), Zagreb 2010., 149-156.

25 Krešimir ČVRLjaK, „Natko Nodilo (1834-1912) i njegova rekonstrukcija hrvatskog i srpskog pravovjerovanja“, Prilozi za istraživanje hrvatske filozofske baštine, 10/1984., br. 1-2 (=19-20), 97-124.
} 
Radi se o konstruktu prema kojem se narod pokazuje kao čuvar priča i pjesama, odnosno skrovište mita. I dalje, narod koji je i sam simbolička konstrukcija, postaje izvorom semioze, konstrukcije novog znaka u vidu nad-lokalnog političkog identiteta. Znamo li da je upravo lokalnost sve do 19. stoljeća bivala presudna u određivanju separatnih identiteta malih dalmatinskih sredina, nad-lokalni identitet se gradi u vidu nacionalnog, a, u primjeru južnoslavenske ideologije, nad-nacionalnog bića kao „prvog“ i dominantnog, štoviše jedinog identiteta koji u vidu sinteze potire nekadašnje podjele na urbane „prve“ i ruralne „druge“. Na političke i publicističke konotacije toga procesa upozorava nas već spominjana studija Nikše Stančića, ${ }^{26}$ ali važniju referencu predstavljat će rad Jasne Čapo Žmegač, koja upozorava na kulturološki obuhvatniji proces. ${ }^{27}$ Naime, u trenutku kad narodnjački intelektualci poput Nodila afirmiraju narod kao izvor predodžbenih slika ključnih za konstrukciju nad-lokalnog identiteta u Dalmaciji, upravo folklor postaje pozornicom na kojoj se ta konstrukcija odvija: Jasna Žmegač Čapo detektira kako se pritom realni etnički folklor odmjenjuje imagološkom konstrukcijom, odnosno folklorom etniciteta. ${ }^{28}$ To nije samo dalmatinski ili južnoslavenski specifikum. Dapače, radi se o općem mjestu nastanka europskih nacija u 19. stoljeću, o čemu nas u radu s opsežno citiranom popratnom literaturom na temu nacionalne konstitucije grčkog identiteta obavještava Theodore G. Zervas. ${ }^{29}$

Ovdje je važno uočiti da svaka konstrukcija nad-lokalnog, pa onda i nacionalnog identiteta biva praćena etičkim i estetičkim platformama. U tom smislu svaka šira društvena identifikacija podrazumijeva izražajnu, najčešće vizualnu uniformiranost; obrazac uniformiranosti izražava dominantne političke, socijalne i konačno ideološke odrednice. ${ }^{30}$ Tako se konstruira dominantno „jastvo“, onaj „nacionalni prvi“, koji najčešće nema povijesnog uporišta, ali mu treba imagološki relevantna slika u cilju vlastite afirmacije. $S$ tim u vezi, estetička vizija koju donosi narodnjačka ideja na našim prostorima konačno se vizualno oblikuje u kiparskom opusu Ivana Meštrovića i - djelomično - njegovog splitskog umjetničkog kruga. Temelje toj viziji Meštrović je udario ranim Kosovskim ciklusom (1908. 1914.), koji nije drugo do vizualna transformacija ciklusa južnoslavenskih narodnih epskih pjesama. ${ }^{31} \mathrm{Ne}$ treba sumnjati da se ovdje radi o impresivnom, u nas do tada nezabilježenom pokušaju vizualizacije aretističke „etike stida“, vezane uz narodno stvaralaštvo koje se referira na nadiranje otomanskog imperija na Balkan. U tom kontekstu središnje mjesto zadržava faktična bitka na Kosovu polju iz 1389., s pripadajučim dramatis personama opjevanim u narodnoj epici. Ovdje nam nije namjera ulaziti u ionako poznata politička opredjeljenja mladog Meštrovića, već želimo upozoriti na temeljnu imagološku odrednicu Kosovskog ciklusa.

\footnotetext{
26 N. STANČIĆ, „Nacionalna integraciona ideologija“, 183-279.

27 Jasna ČAPO ŽMEgAČ, „Plaidoyer za istraživanje (nacionalnog) identiteta u hrvatskoj etnologiji“, Etnološka tribina, 24/1994., br. 17, 7-23.

28 Isto.

29 Theodore G. Zervas, „(Re)creating a National Identity in 19th Century Greece: National Identity, Education, and European Perceptions of Greece" (https://www.academia.edu/2084653/_Re_Creating_a_National_Identity_ in_19th_Century_Greece_National_Identity_Education_and_European_Perceptions_of_Greece).

30 Dana Arnold (ur.), Cultural identities and the aesthetics of Britishness, Manchester 2004., 1-14.

31 Duško KečKemet, Ivan Meštrović (monografija), Zagreb - Ljubjana 1970., uvodni tekst bez paginacije.
} 
Naime, originalna narodna epika Kosovskog ciklusa temelji se na tzv. „kolektivnim likovima“ koji reprezentiraju grupne identitete vezane uz etičke ideje. Ti su identiteti vezani uz muške motive mučeništva, izdaje i herojstva (utkanih u dramatis personae poput Kneza Lazara, Miloša Obilića ili Vuka Brankovića), odnosno ženske motive predanosti (Kosovka djevojka, majka braće Jugovića). Meštrović je, pak, herojsku i aretističku epiku Kosovskog ciklusa shvatio u vidu metafore koja obilježava kolektivna povijesna iskustva svih južnoslavenskih naroda pa je - prebacujući jezične motive etničkog folklora u skulpturu - zapravo stvorio temelje za imagološki relevantnu vizualnu definiciju folklora etniciteta. Taj će autorov postupak u kontekstu kasnijeg Njegoševog mauzoleja na Lovćenu prepoznati Vinko Srhoje kao stilsku kreaciju ,ahistorijskog idealizma“", 32 no suštinski se radi o imagološkom konstruiranju kolektivnih identiteta koji počivaju na etičkim pretpostavkama. Ovdje

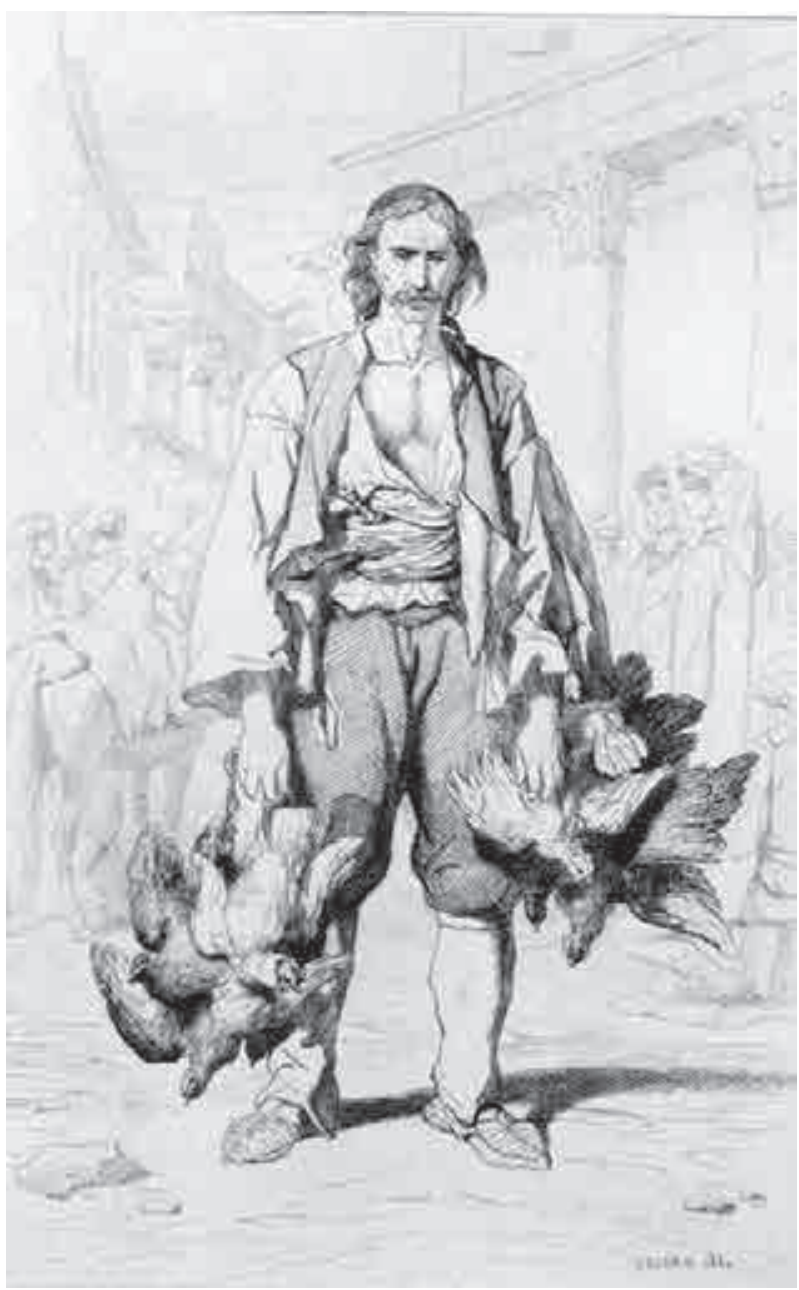

Sl. 2. Théodore Valerio, Morlak iz okolice Splita (1864.) je važno podcrtati da je Meštrovićeva konstrukcija kolektivnog identiteta utemeljena upravo na onome što bi Fortis prepoznao kroz sintagmu „morlačke etike“. Vrlo sličan postupak u romanu Zimsko ljetovanje koristi i Vladan Desnica opisujući svijet ruralne Dalmacije. Pisac pritom stvara slike kolektivnih uvjerenja, simboliziranih, primjerice, u motivu polaganja zakletve četničkom vojvodi, a osobito u motivu kolektivne šutnje Smiljevčana spram nasilja hajduka koji su, zapravo, njihovi vlastiti suseljani. ${ }^{33}$

Vladan Desnica u romanu opisuje, ali ne osuđuje ruralnu i kolektivističku „etiku stida“ s pozicija individualizirane građanske ,etike krivnje“ i ideologije dominantnog građanskog „jastva“. No, zanimljivo je primijetiti, Meštrovićev su „ahistorijski idealizam u nastajanju“ u Rimu 1911. godine prepoznali i negativno ocijenili sljedbenici filozofa i estetičara Bene-

\footnotetext{
32 Vinko SrhoJ, „Ivan Meštrović i politika kao prostor ahistorijskog idealizma“, Ars Adriatica, 4/2014., 369-384.

33 V. Desnica, Zimsko ljetovanje, 131-133, 157.
} 
detta Crocea. Tako kročeanac, povjesničar i istaknuti liberal Guglielmo Ferrero u Meštrovićevom opusu vidi arhajski barbarizam kao izraz onog negrađanskog, a mi bismo dodali i „drugog ${ }^{34}{ }^{34}$ Ovdje treba otvoriti zagradu te primijetiti kako se nimalo zanemariv dio čak i kasnijeg kiparskog opusa Ivana Meštrovića može smatrati imagološki relevantnom vizualizacijom narodnjačke ideologije, koja naposljetku završava jugoslavenskim političkim programom. Meštrović je upravo tim, uvjetno rečeno, „narodnjačkim motivima“ - ikonografski utemeljenim na dinaridskom folkloru i „etici stida“ - utjecao na niz učenika i sljedbenika, a posebno onih koji su se okupljali oko radionice na splitskim Mejama. Ovdje ne mislimo samo na autore poput Tome Rosandića i Marina Studina, nego daleko više na autore mlađe generacije, kao što su bili Ivo Lozica, Grga Antunac i, najviše od svih, Andrija Krstulović. Studinovi motivi vlaških žena, Antunčev ciklus Zlarinki ili Krstulovićevi motivi Pastira s kozletom izvedeni su upravo iz Meštrovićevog „narodnjačkog“ instrumentarija.

Zatvarajući zagradu, nužno je primijetiti kako i Vladan Desnica kroz galeriju smiljevačkih likova u romanu Zimsko ljetovanje opisuje neke od temeljnih etičkih i estetičkih sastavnica te dinaridske, „narodnjačke“ Dalmacije, koja se javlja već u zaleđu dalmatinskih gradova. Pisac im suprotstavlja likove Zadrana i njihov građanski etos oličen - kako smo već primijetili - u „etici krivnje“. No, postoji li estetička platforma putem koje su građani opisani? Vladan Desnica se u mladosti smatrao sljedbenikom misli Benedetta Crocea, što je naposljetku i potvrdio prevodeći Croceove estetičke eseje. ${ }^{35}$ Kročeanstvo je, pak, do izvjesne mjere bilo poznatom doktrinom u Splitu i Dalmaciji tijekom prve polovine 20. stoljeća, a samog Crocea (1866. - 1952.) smatralo se sinonimom liberalne misli i klasične građanske kulture. Iz te nas perspektive čudi činjenica da kročeanstvo u Dalmaciji nije značajnije utjecalo na umjetničku produkciju i kritiku, ali nas ne iznenađuje Ferrerovo kročeanski intonirano odbijanje Meštrovićevog „narodnjačkog kolektivizma“ pretočenog u skulpturu.

Otvorimo li, pak, novu zagradu, ovaj put posvećenu Croceu - i njegovom mogućem utjecaju na Desničin opis urbanog miljea - valja započeti činjenicom da je Croceova estetička misao vezana uz tada popularno opredjeljenje imanentizma, prema kojem temeljne istine postoje samo u kontekstu neposrednog čovjekovog iskustva i povijesti kao takve. ${ }^{36}$ Nemoguće ih je, dakle, naći u vidu transcendentnih apsoluta pa stoga vrijedi i kročeanska krilatica kako „nema univerzalnih istina“. Poznajemo li temelje Croceovog sagledavanja uloge povijesne i intuicionističke dimenzije za narav naše spoznaje, naziremo temelje mogućeg čitanja odbojnosti kročeanca Guglielma Ferrera nad Meštrovićevim ranim opusom: arhajska, pseudo-didaktična priroda Meštrovićevih bezvremenskih, herojskih i kolektivistički intoniranih likova morala mu je biti sasvim strana.

Zatvarajući zagradu valja nam se vratiti Desničinom romanu Zimsko ljetovanje, koji je - čini nam se - u segmentima posvećenima gradu Zadru i njegovim stanovnicima sasvim kročeanski intoniran. Opis građana to na izvjestan način potvrđuje:

\footnotetext{
34 Duško KečKemet, „Ivan Meštrović u Italiji“ (http://mestrovic.kkz.hr/web_redizajn/KONGRES.htm).

35 Benedetto Croce, Eseji iz estetike, Split 1938.

36 Vidi: Gian Napoleone Giordano Orsini, Benedetto Croce. Philosopher of Art and Literary Critic, Carbondale 1961.

37 V. Desnica, Zimsko ljetovanje, 81.
} 
Građani umiju da rasporede vrijeme: raskroje svoj dan, razdijele ga na odsječke, između odsječaka poudaraju pregradice čvrste i nepokolebive kao zakon; odsječke ispune dužnostima, navikama društvenim obavezama i obzirima, brigom za svoje tijelo, za svoju bradu, za svoje nokte, i koječim sličnim - ako ničim drugim, a ono jadanjem na dugočasnost i mišlju o svojoj zloj kobi. Tako rascjepkano, vrijeme se lakše svladava i konsumira. ${ }^{37}$

U citiranom odlomku nalazimo ne samo opis sasvim osobnog, iskustvenog izražavanja spoznaje, već i latentno prisutnu fenomenološku dimenziju odnosa prema vremenu koja se osim kod Crocea osjeća i u Desničinoj prozi te koja će se konačno pretočiti u egzistencijalističko tkivo romana Proljeća Ivana Galeba iz 1957. Teško je tvrditi da je egzistencijalizam kasne Desničine proze uvjetovan Croceovom estetikom, utoliko više jer je poznato da su talijanski egzistencijalisti odbijali Crocea zbog njegove sklonosti intelektu i historicizmu. ${ }^{38}$ Stoga je uputnije zaustaviti se na Croceovom shvaćanju imanentizma, i to na podlozi filozofove teorije o podudarnosti iskustva, intuicije i izraza. Zanimljivo je, pritom, da Croce - u kontekstu prvog eseja o estetici koji Desnica prevodi još 1932. godine - odbacuje empirizam, prakticizam i intelektualizam te intuiciju promovira na hajdegerovski način: „Zamislimo čovjeka koji se prvi puta otvara teoretskom životu, s okom čistim od svake refleksije. U tom prvom, čisto intuitivnom času, on nije mogao nego da bude pjesnik. "39 Odatle dolazi do pojave čiste ekspresije - jer je samo ostvareni izraz znak prethodnog postojanja intuicije - odnosno utjelovljenja umjetnika koji spoznaje kroz vlastiti izraz. ${ }^{40}$ Umjetnik je, dakle, onaj koji ekspresiju dostiže neposredno, izbjegavanjem „deklamacija i teatarskih efekata“ i koji u djelo ne uvlači ono što je djelu kao takvom strano. ${ }^{41}$ Jasno je da se radi o estetičkom intuicionizmu te, šire, o fenomenološkoj poziciji koja naglašava pojedinačnu svijest i stoga subjektivnu perspektivu spoznaje.

Dosad je bilo manje ili čak nikako istraženo koliko Desničini opisi razorenog Zadra - intonirani toliko drugačije od opisa Smiljevaca - duguju upravo kročeanskoj verziji fenomenologije, jer - budući da su lišeni svake dodatne značenjske vrijednosti - dolaze na rub vježbe u opažanju fenomena. $U$ tom je smislu gotovo paradigmatičan Desničin interes za motive ruševnih gradskih kuća ogoljele nutrine („pošteđen luster koji mirno visi u prepolovljenoj sobi“). ${ }^{42}$ Takvi motivi opis grada svode na razinu mrtve prirode, odnosno teksta ogoljena od svakog sebi izvanjskog smisla. Arthur Schopenhauer na ovom bi mjestu primijetio kako su objekti koji čine mrtvu prirodu izdvojeni iz svojih uobičajenih, uzročno-posljedičnih tijekova te kao izolirani fenomeni dovedeni u neočekivane odnose unutar kojih ih možemo prvi put vidjeti kakvi stvarno jesu. ${ }^{43}$ Ipak, ovako intonirano istraživanje zahtijeva zaseban tekst, a i teško da ga je moguće poduprijeti tada aktualnim književnim primjerima usporedivima romanu Zimsko ljetovanje.

\footnotetext{
38 Charles L. Killinger, Culture and Customs in Italy, Westport 2005., 54.

39 B. Croce, Eseji iz estetike, 19.

40 Isto, 20.

41 Isto, 23.

42 V. Desnica, Zimsko ljetovanje, 56.

43 Vidi: Dale Jacquette (ur.), Schopenhauer, Philosophy and the Arts, New York 2007.
} 


\section{ZAKLJUČAK}

Desničino suprotstavljanje dvije Dalmacije i dva pripadajuća im etosa u tekstu romana Zimsko ljetovanje zanimljivo je prije svega zbog analogije piščevog opisa ruralne Dalmacije s Fortisovom „morlačkom etikom“, odnosno aretističkom „etikom stida“. Ivan Meštrović će na temelju te „druge“ etičnosti sagraditi galeriju „kolektivnih identiteta“ koji će uprizoriti nacionalni i nadnacionalni, južnoslavenski identitet prispodobiv novoj političkoj zajednici Srba, Hrvata i Slovenaca. Njegov je rad višestruko značajan, i to zbog dvije imagološki relevantne činjenice. Prvo, upravo u trenutku nastanka, u njemu se fokusira razvoj više desetljeća „narodnjačke ideologije“ na ovim prostorima. Drugo, zbog velikog utjecaja koji su u našoj kulturnoj sredini imali Meštrović i njegovi neposredni sljedbenici, isti će „kolektivni identiteti“" $s$ neznatnim ikonografskim preinakama (koje folklor etniciteta zamjenjuju folklorom klasnih obilježja, a svetosavsku etiku onom revolucionarnom) ostati referentne točke i u oblikovanju javnih plastika nastalih nakon Drugog svjetskog rata. Ipak, promatramo li liniju Meštrovićevog utjecaja bez ikonografskih varijacija, treba reći da će njezin posljednji sljedbenik ostati Andrija Krstulović kao najmlađi član radionice na Mejama; njegove splitske javne plastike iz sedmog desetljeća poput skulptura Čobanica i Pozdrav suncu dosljedno čuvaju Meštrovićevu „narodnjačku ikonografiju“. Sitne Krstulovićeve plastike u terakoti, pak, razvijaju istu ikonografiju do mediteranskih razmjera, povezujući je u konačnom izvodu s antičkim mitom o Edipu i egipatskom skulpturom. Naglašavamo da Krstulović time ne izlazi iz sfere Meštrovićevog utjecaja, već joj samo dodaje kulturološki širu dimenziju.

Ovdje bi, dakako, trebalo otvoriti pitanje što se najposlije dogodilo s onim drugim, građanskim polom romana Vladana Desnice? Već smo spomenuli kako roman završava stvarnim i simboličkim proždiranjem gradskog djeteta: proždire ga prasac Migud. Miljenko Jergović, pak, napominje kako je Desnica ostavio ključeve čitanja teksta opaskom da neki od zadarskih egzilanata migriraju u Italiju, dok se neki vraćaju u neizvjesnu zadarsku budućnost. ${ }^{44}$ Svi će oni najprije ponijeti etiketu „drugih“, a potom biti marginalizirani u okvirima novog, radikalno „narodnog“ poslijeratnog poretka, zajedno s građanskom Dalmacijom i - ako ih je uopće još bilo - sjećanjima na Benedetta Crocea. Jer, neformalni svijet splitskih i dalmatinskih kročeanaca - u koje je pripadao i Vladan Desnica - rodio se u prijeratnoj Dalmaciji, da bi se u onoj poslijeratnoj pretvorio u mit o kročeanskom poimanju individualnog umjetničkog izraza. ${ }^{45}$ Štoviše, za razliku od meštrovićanskog „narodnjaštva“ koje je - imagološki gledano - proizvelo priličan broj vlastitih varijacija, kročeanstvo i općenito građanska misao u Dalmaciji stvorili su zanemarivu količinu imagološki relevantnih predodžbi o sebi, da bi najposlije izblijedili u poslijeratnom internacionaliziranju umjetničkog ukusa. Ipak, ključno mjesto u tom skučenom rasponu zauzima intimistički opus Emanuela Vidovića, koji - upravo u kontekstu mrtve prirode i prikaza enterijera - već tijekom trećeg desetljeća 20. stoljeća dostiže autentično imanentističke pozicije u slikarstvu.

44 V. Desnica, Zimsko ljetovanje, 160.

45 Vladan Desnica, „Benedeto Kroce i zbrka oko njega“, Eseji, kritike, pogledi, Beograd 1993., 163. 
S dugovječnim Vidovićevim djelovanjem nestala bi i ta usamljena pozicija umjetnika koji se prepoznaje kretanjem između intimističkog motiva i imanentističkog izvoda njegove obrade, da Vidovićeva istraživanja nije naslijedio Marino Tartaglia. Poput Vidovića školovan u Italiji Croceovog doba, Tartaglia će proći intimističku fazu razvoja, da bi nakon Drugog svjetskog rata, tijekom sedamdesetih godina, u radikalnim obradama (ponovno intimističkih) motiva Cvijeće, odnosno Pogled s prozora stigao na prag apstraktnog slikarstva i - slično Desnici - egzistencijalističkih pozicija. Tartaglijino, pak, nasljeđe ponijeli su i nastavili razvijati neki od polaznika njegove klase na zagrebačkoj Akademiji likovnih umjetnosti, ali se u Dalmaciji nepovratno ugasilo.

Roman Zimsko ljetovanje Vladana Desnice, pak, da se vratimo ocjenama Miljenka Jergovića, doista ostaje prvim i jedinim građanskim romanom o Drugom svjetskom ratu u hrvatskoj i srodnim joj književnostima. Promatrajući ruralni svijet kao „drugoga“, Desnica kroz usta i oči svojih građanskih likova daje pogled na stvarnost koji je u godini izlaženja romana već anakron. Ne čude, stoga, napadi na njega zbog teksta koji se oglušio o nužnost da književnost bude didaktički i normativno osviještena, ne trpeći sukob „prvog“ i „drugog" nikako drugačije nego kroz klasni antagonizam. Pišući obranu vlastitom romanu, Desnica će posredno braniti i kročeanski imanentizam - ili bar pravo na osobno tumačenje istog - a s njim i Dalmaciju sazdanu na fortisovskom viđenju „građana“ i onih „drugih“, a koja je već tada prebivala samo u njegovim sjećanjima. ${ }^{46}$

\section{$\cos$}

\section{Vladan Desnica's Novel Zimsko ljetovanje in the Context of Cultural Studies}

The paper focuses on the relationship of urban and rural identities in Dalmatia, seen through the prism of the novel Zimsko ljetovanje (The Winter Holiday, 1950), written by Vladan Desnica. Also in the context of the novel, the paper deals with two imagologically relevant paradigms: the first is close to Benedetto Croce's immanentism, and the other, far more influential, is featured as a construction of a "national" and "pan-national" aesthetic model, visible in segments of the sculptural work of Ivan Meštrović and his followers in Split. The analytical tools used to examine the paradigms mentioned are based on the intertwining of two theoretical models: "theory of the other" ("theory of identity construction") and the study of imagology. Imagological terminology - relevant to the relationship between urban and rural codification in Dalmatia - stems from the opposition of "populism" and "Italianism," where both orientations build their own identity construction. Far more successful was the "populist" orientation, especially in the context of the romantic vision of South Slavic ideology; it was brought to life primarily in Meštrovićs sculptural Kosovo cycle, and then in the works of his followers and associates. The contrast of urban and rural coding in Dalmatia can be traced back to at least the $18^{\text {th }}$ century, to Alberto Fortis' travelogue Travels into

46 Vladan Desnica, „O jednom gradu i o jednoj knjizi“, Eseji, kritike, pogledi (= Sabrana djela Vladana Desnice, knj. IV), Zagreb 1975., 92-104. 
Dalmatia that inaugurated the Morlach entity as the ethical and cultural opposition to the urban identity of Dalmatian cities. Vladan Desnica used this dichotomy as the underlying structure of his novel The Winter Holiday, and he built on it - in the words of Miljenko Jergović - the first and only urban novel about World War II in Croatian literature.

Key words: Vladan Desnica, Zimsko ljetovanje, Benedetto Croce, Ivan Meštrović, folklore of ethnicity, identity, "theory of the other"

\section{$\cos$}

\section{Literatura}

Toma ArhiĐakon, Kronika, Split 1960.

Dana Arnold (ur.), Cultural identities and the aesthetics of Britishness, Manchester 2004.

Manfred Beller - Joep Leerssen, Imagology. The Cultural Construction and Literary Representation of National Characters, Amsterdam - New York 2007.

Joseph M. Bryant, Moral Codes and Social Structure in Ancient Greece. A Sociology of Greek Ethics From Homer to the Epicureans and Stoics, NewYork 1996.

Lisa Colletta (ur.), The Legacy of Grand Tour, New Jersey 2015.

Benedetto Croce, Eseji iz estetike, Split 1938.

Jasna ČAPO ŽMEGAČ, „Plaidoyer za istraživanje (nacionalnog) identiteta u hrvatskoj etnologiji“, Etnološka tribina, 24/1994., br. 17, 7-23.

Krešimir ČvrluaK, „Natko Nodilo (1834-1912) i njegova rekonstrukcija hrvatskog i srpskog pravovjerovanja“, Prilozi za istraživanje hrvatske filozofske baštine, 10/1984., br. 1-2 (=19-20), 97-124.

Vladan Desnica, „Benedeto Kroče i zbrka oko njega“, Eseji, kritike, pogledi, Beograd 1993., 163.

Vladan DesnicA, „O jednom gradu i o jednoj knjizi“, Eseji, kritike, pogledi (= Sabrana djela Vladana Desnice, knj. IV), Zagreb 1975., 92-104.

Vladan Desnica, Zimsko ljetovanje; Pripovijesti (= Pet stoljeća hrvatske književnosti, knj. 117, prir. Vlatko Pavletić), Zagreb 1968.

Davor Dukıć, „Nekoliko imagoloških opaski o Zimskom ljetovanju i Desničinim susretima“, Desničini susreti 2005. - 2008. Zbornik radova (ur. Drago Roksandić i Ivana Cvijović Javorina), Zagreb 2010., 149-156.

Alberto Fortis, Put po Dalmaciji, Split 2004.

Stuart Hall - Paul du GAY (ur.), Questions of Cultural Identity, London 2011.

Dale Jacquette (ur.), Schopenhauer, Philosophy and the Arts, New York 2007.

Miljenko Jergović, „Vladan Desnica: Hitac veselnik“, Subotnja matineja (http://www.jergovic. com/subotnja-matineja/vladan-desnica-hitac-veselnik/).

Duško KečKemet: Ivan Meštrović (monografija), Zagreb - Ljubjana 1970.

Duško KečKemet, „Ivan Meštrović u Italiji“ (http://mestrovic.kkz.hr/web_redizajn/KONGRES. htm).

Duško Kečkemet, Robert Adam: Dioklecijanova palača i klasicizam, Zagreb 2003.

Charles L. Killinger, Culture and Customs in Italy, Westport 2005.

Gian Napoleone Giordano Orsini, Benedetto Croce. Philosopher of Art and Literary Critic, Carbondale 1961. 
Edward SAID, Orientalism, London 1978.

Mirna Sindičić SABljo, „Predodžbe o ruralnoj sredini u Zimskom ljetovanju Vladana Desnice“, Fluminensia, 23/2011., br. 1, 131-142.

Vinko SRHoJ, „Ivan Meštrović i politika kao prostor ahistorijskog idealizma“, Ars Adriatica, 4/2014., 369-384.

Nikša STANČıć, „Nacionalna integraciona ideologija dalmatinskih narodnjaka 1860/61. godine“, $R a$ dovi Zavoda za hrvatsku povijest, 11/1978., 183-279.

Alen TAFrA, „Dodir Mediterana i Istočne Europe u svjetlu 'filozofske geografije'“, Metodički ogledi, 18/2011., br. 1, 67-82.

Eva-Marie Tvert, „Folklore on Display: The Authenticity Debate Revisited“, Studia ethnologica Croatica, 19/2007., 293-302.

Theodore G.. Zervas, „(Re)creating a National Identity in 19th Century Greece: National Identity, Education, and European Perceptions of Greece“ (https://www.academia.edu/2084653/_ Re_Creating_a_National_Identity_in_19th_Century_Greece_National_Identity_Education_ and_European_Perceptions_of_Greece).

Zdravko Zima, Zimsko ljetovanje. Ogledi \& kronike, Zagreb 2001. 